\title{
NOTE
}

\section{Recurrence of Thalassia testudinum seagrass die-off in Florida Bay, USA: initial observations}

\author{
Margaret O. Hall ${ }^{1}$, Bradley T. Furman ${ }^{2}$, Manuel Merello ${ }^{1}$, Michael J. Durako ${ }^{3}$
}

${ }^{1}$ Florida Fish Wildlife Conservation Commission, Florida Fish and Wildlife Research Institute, 100 Eighth Avenue, Southeast, St. Petersburg, FL 33701, USA

${ }^{2}$ Department of Environmental Sciences, University of Virginia, 291 McCormick Road, Charlottesville, Virginia 22904, USA

${ }^{3}$ University of North Carolina at Wilmington, Center for Marine Research, 7205 Wrightsville Avenue, Wilmington, NC 28403, USA

\begin{abstract}
Widespread mortality of Thalassia testudinum was first documented in Florida Bay, USA, during the summer of 1987 . This unprecedented event spanned $3 \mathrm{yr}$, affected $40 \mathrm{~km}^{2}$ of seagrass and resulted in more than a decade of ecological disturbances. Initial putative causes for seagrass die-off ranged from climatic anomalies and watershed changes to wasting disease and eutrophication. Subsequent experimental research suggested that hypoxic plant tissue, caused by low water column oxygen content or reduced photosynthesis, allowed intrusion of sulfide leading to plant death. Contributing factors included high temperatures, salinities and T. testudinum biomass, together causing lower oxygen water solubility, higher community respiration rates and elevated nighttime oxygen demand. The Fisheries Habitat Assessment Program (FHAP) has tracked the system's slow recovery since 1995. Recent FHAP data (2012) indicated that T. testudinum had returned to pre-die-off densities in even the most severely affected locations. During the summer of 2015, following several months of drought, National Park Service researchers reported hypersaline conditions and a recurrence of seagrass die-off in north-central Florida Bay. An interagency effort is presently underway to document the duration, extent, impacts and possible factors responsible for the current mortality. Initial field surveys indicate that there is high spatial coincidence between the current and the 1987-1990 events and that hypersalinity, water column stratification and bottom-water anoxia might have once again resulted in mass mortality of $T$. testudinum in Florida Bay. The goal of this report is to alert the scientific community to the recurrence of this important ecological event.
\end{abstract}

KEY WORDS: Thalassia $\cdot$ Die-off $\cdot$ Hypersalinity $\cdot$ Sulfide toxicity $\cdot$ Recovery $\cdot$ Cyclic

\section{INTRODUCTION}

Florida Bay is a shallow (1-2 m depth), triangularshaped estuary located between the Florida mainland and the Florida Keys, USA (Schomer \& Drew 1982). Despite its large size $\left(2200 \mathrm{~km}^{2}\right)$ and nearly flat limestone foundation, the bay actually consists of a loosely connected network of 45 seagrassdominated basins (sometimes referred to as 'lakes') separated by shallow subtidal to intertidal carbonate

${ }^{*}$ Corresponding author: penny.hall@myfwc.com mudbanks, which cover nearly $25 \%$ of the bay (Peterson et al. 2006, Hall et al. 2007). Wind-driven circulation maintains vertically well-mixed water column conditions throughout most of the year (Wang et al. 1994). However, because much of the interior bay exhibits microtidal ranges and sheet or managed freshwater flows from the Everglades contribute little to basin renewal, water exchange among basins is limited to a few narrow tidal channels (Rudnick et al. 1999, Hall et al. 2007, Lee et al. 2016). Thus, salinities 
differ widely among basins, and they are particularly affected by the onset and intensity of wet-season rainfall (June through October). This results in frequent, spatially restricted episodes of hypersalinity, mostly in the spring and early summer. For northcentral basins with water residence times of 6-12 mo (Lee et al. 2008, 2016), spring and early summer salinities commonly exceed 40-50 PSU (Nuttle et al. 2000). On longer timescales, trends in baywide salinity reflect human management of south Florida hydrology, with east-west diversion of sheetflow significantly reducing historical freshwater delivery to Florida Bay (Kendrick et al. 2012, Marshall et al. 2014).

Seagrass communities within Florida Bay form some of the largest continuous meadows in the Northern Hemisphere (approximately $2000 \mathrm{~km}^{2}$; Fourqurean \& Robblee 1999). Across the bay, patterns in seagrass density and productivity reflect gradients in sediment depth and macronutrient availability, increasing from the northeast to the southwest (Zieman et al. 1989, Fourqurean et al. 1992). Within basins and on bank tops, turtlegrass Thalassia testudinum is generally the dominant seagrass species; however, Halodule wrightii and Syringodium filiforme are frequently present, forming mixed meadows with species proportionality related to water quality and successional state (Zieman et al. 1989). Primary and secondary productivity within these meadows support economically important populations of pink shrimp Farfantepenaeus duorarum, stone crab Menippe mercenaria and spiny lobster Panuliris argus, as well as state and federally protected species, such as bald eagle Haliaeetus leucocephalus, manatee Trichechus manatus, American crocodile Crocodylus acutus and green sea turtle Chelonia mydas (Robblee et al. 1991, Boesch et al. 1993, Hall et al. 2007).

In the late summer of 1987, extensive areas of dead and dying $T$. testudinum were reported in northcentral Florida Bay (Robblee et al. 1991, Fourqurean \& Robblee 1999). Unprecedented in speed (weeks to months), species-selectivity ( $T$. testudinum only) and spatial scale (1000s of ha), the event was further noted for small-scale (10s of $\mathrm{m}$ ) patchiness, a reticulated distribution and sharp transitional boundaries with remnant beds. The die-off was initially most prevalent in dense $T$. testudinum adjacent to mud banks, but subsequently entire basins exhibited mortality. By fall of 1990, approximately 9445 ha of T. testudinum were estimated to be severely affected (Robblee et al. 1991) (Fig. 1a). A multi-year drought (1989-1992) and widespread turbidity due to re-suspended sediments and recurrent algal blooms (be-

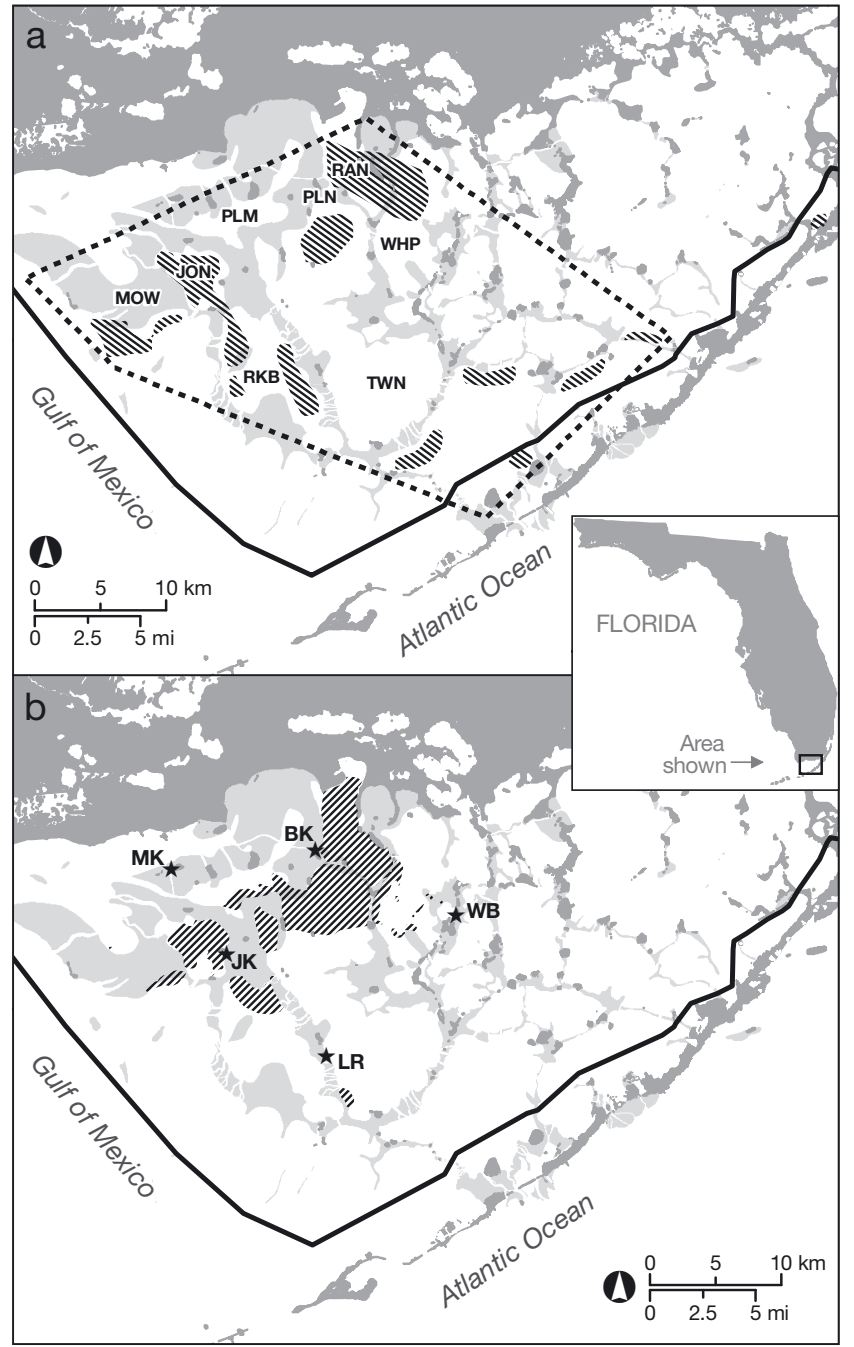

Fig. 1. Known areas of Thalassia testudinum die-off in Florida Bay, USA, during the (a) 1987-1990 and (b) 2015 events. Panel (a) adapted from Robblee et al. (1991). RAN: Rankin Lake; WHP: Whipray Basin; TWN: Twin Key Basin; RKB: Rabbit Key Basin; MOW: Man of War Basin; JON: Johnson Key Basin; PLM: Palm Basin; PLN: Pelican Key Basin. Hatching denotes severely affected areas; dashed line bounds most known occurrences. Solid black line follows the southern boundary of Everglades National Park. Carbonate mudbanks shown as light gray polygons. Starred locations in (b) identify National Park Service monitoring stations: BK (Buoy Key), MK (Murray Key), LR (Little

Rabbit Key), JK (Johnson Key) and WB (Whipray Basin)

ginning 1991) then led to secondary seagrass losses and a cascade of ecological disturbances including a major sponge mortality and brief reductions in $F$. duorarum and P. argus fisheries (Butler et al. 1995, Durako et al. 2002, Peterson et al. 2006). Causal factors have been much debated in the literature (Durako \& Kuss 1994, Zieman 1997, Fourqurean \& Robblee 1999, Zieman et al. 1999; but see Lapointe \& Barile 2004, Zieman et al. 2004); however, a number 
of manipulative studies demonstrated that environmental drivers (i.e. the single or multiplicative effects of elevated summer temperatures and high springsummer salinities) resulting in sustained pore- and bottom-water anoxia can lead to insufficient aeration of roots and rhizomes, toxic levels of sulfide intrusion and plant death (Carlson et al. 1994, Borum et al. 2005, Koch et al. 2007). Freshly dead biomass then supports further microbial sulfate reduction, increasing porewater sulfide concentrations and expanding (and coalescing) small isolated die-off patches into ever-larger sizes (Carlson et al. 1994, Durako et al. 2002). Implicit in this model is the presence of large, dense beds of $T$. testudinum, a species with comparatively high ratios of below- to aboveground biomass, to initiate and sustain large-scale die-off events (Koch et al. 2007). These conditions were reportedly widespread in the central and western portions of Florida Bay prior to 1987 (Zieman et al. 1989).

Following more than a decade of ecological disturbance, turbid conditions subsided and seagrasses began to slowly recolonize the bay in the late 1990s (Durako et al. 2002). In 1995, the Fisheries Habitat Assessment Program (FHAP), a benthic macrophyte status and trends program begun by the Florida Fish and Wildlife Conservation Commission (FWC), began systematically surveying seagrass and macroalgae species composition, distribution and abundance in 10 Florida Bay basins using a modified Braun-Blanquet frequency abundance scale (MuellerDumbois \& Ellenburg 1974, Durako et al. 2002). Over the past $20 \mathrm{yr}$, seagrass community recovery patterns in Florida Bay have largely followed classic paradigms of $T$. testudinum succession with primary colonization and early increases by $H$. wrightii and $S$. filiforme in affected die-off basins (Fig. 2). Recent FHAP data indicated a near-full recovery of $T$. testudinum-dominated communities in the mostaffected basins of Rankin Lake and Johnson Key Basin by 2012. T. testudinum in the north-central bay appeared to be robust during the May 2015 survey, and there were no signs of die-off.

In mid-July 2015, National Park Service (NPS) researchers reported (1) elevated salinities, (2) 2 major fish kills: Gulf toadfish Opsanus beta and pinfish Lagodon rhomboides, (3) signs of renewed T. testudinum die-off and (4) a bright yellow, sulfur-rich, anoxic brine, resembling a 'yellow fog', present within die-off patches and tidal channels in the north-central portion of the bay (V. McGee-Absten pers. comm.; Fig. 3 and Fig. S1 in the Supplement at www.int-res.com/articles/suppl/m560p243_supp.pdf). Although bottom-water temperatures were season-

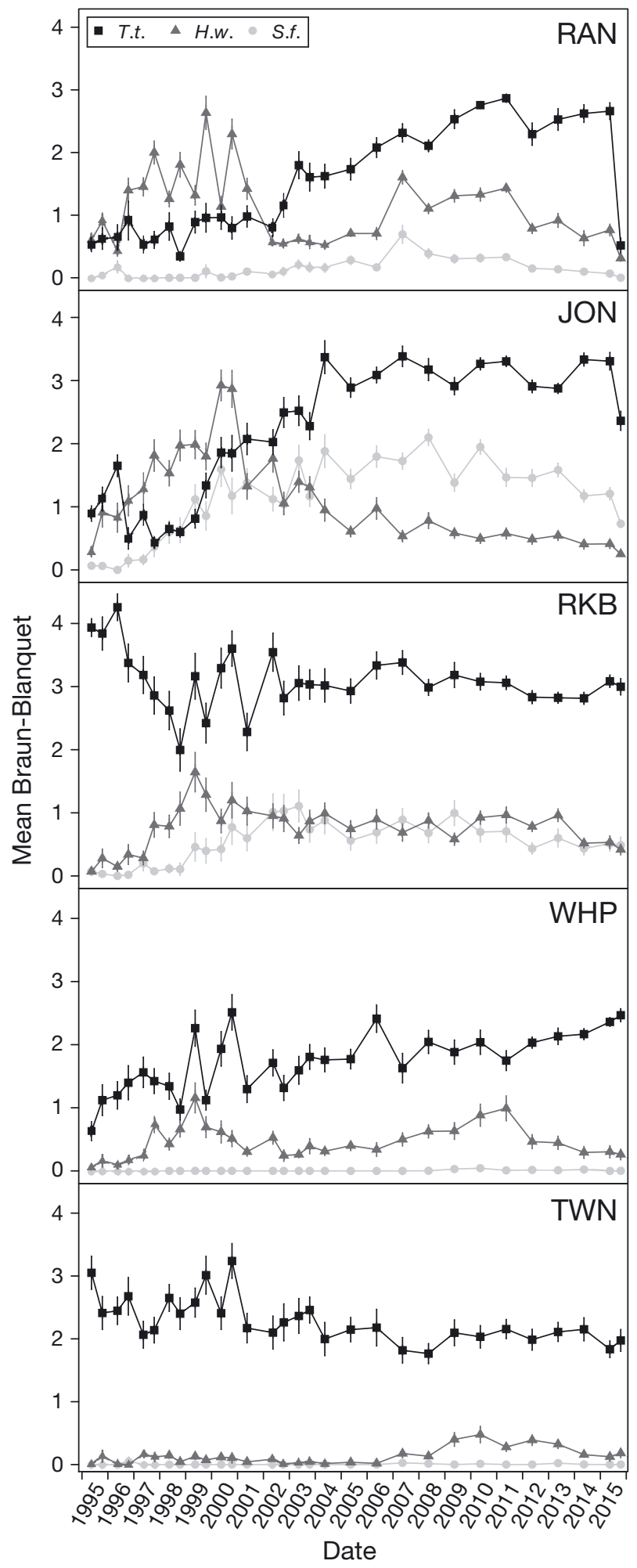

Fig. 2. Time-series of Braun-Blanquet scores for Thalassia testudinum (T.t.), Halodule wrightii (H.w.) and Syringodium filiforme (S.f.) by basin, 1995-2015. Data are expressed as means \pm 1 SD. RAN: Rankin Lake; JON: Johnson Key Basin; RKB: Rabbit Key Basin; WHP: Whipray Basin; TWN: Twin Key Basin. Note precipitous declines in T. testudinum Braun-Blanquet densities in RAN and JON in fall 2015 


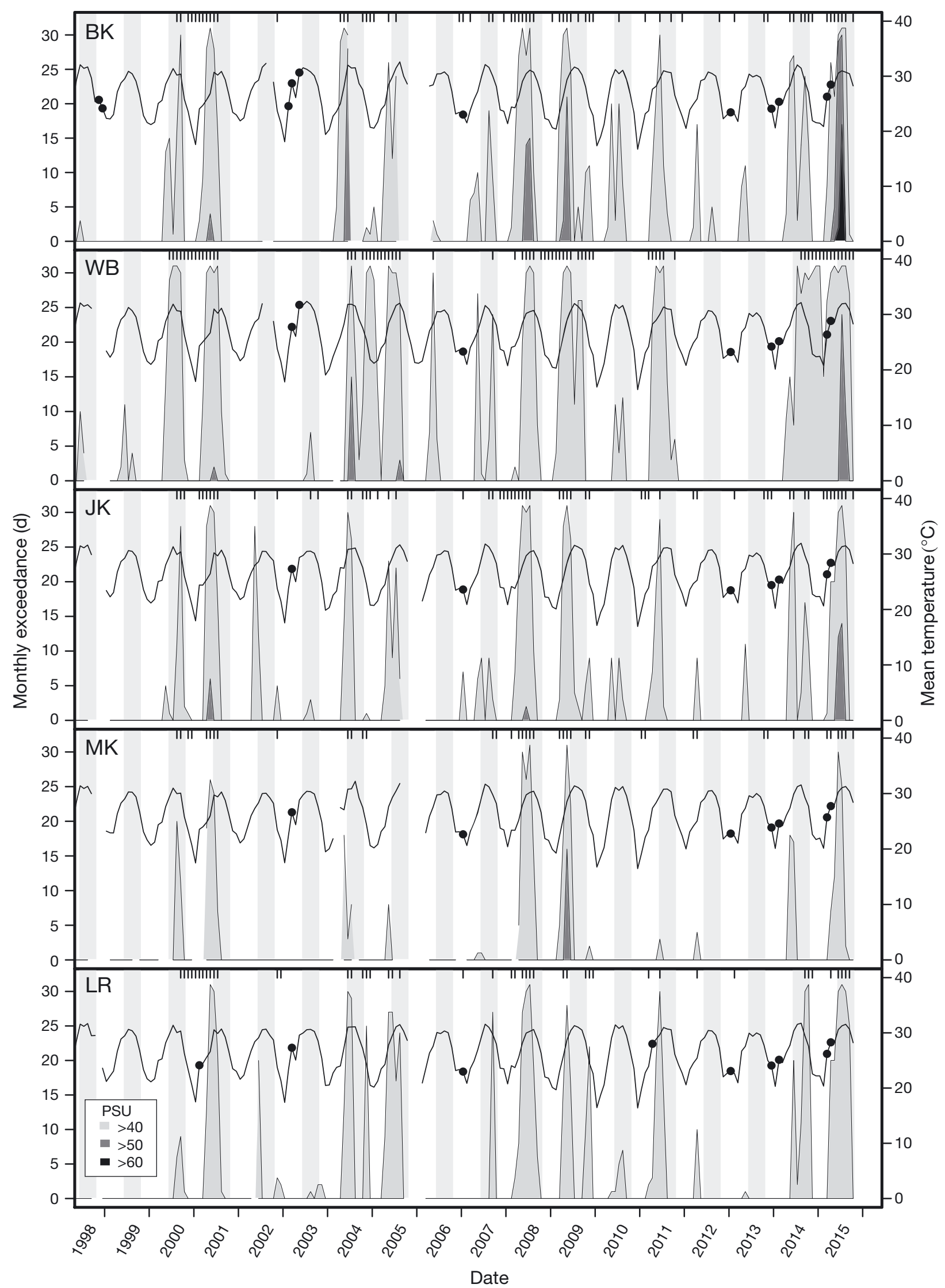


Fig. 3. Time-series of bottom-water salinity (shaded peaks) and temperature (solid black line) data obtained from the National Park Service long-term monitoring stations: BK (Buoy Key), WB (Whipray Basin), JK (Johnson Key), MK (Murray Key), and LR (Little Rabbit Key). Salinity data expressed as the number of days per month that the daily mean salinity exceeded each of 3 thresholds: 40 (light gray), 50 (medium gray) and 60 (dark gray). Months with $>5$ missing daily means were excluded from analysis. Temperature data were plotted as monthly means. Monthly mean salinity (tick marks on the upper $x$-axis) and temperature (0) anomalies of $>2$ (PSU or ${ }^{\circ} \mathrm{C}$, respectively) were determined relative to mean monthly normals calculated across the available times-series per station. Shaded bars denote the annual wet season, June through October

ally high, salinities in Rankin Lake, Johnson Key and Whipray Basins reached 15 yr highs (exceeding 50-60 PSU) and were sustained at these levels over multi-week periods during the late summer. The area where fish kills were observed exhibited a highly stratified water column with bottom salinities and water temperatures exceeding $65 \mathrm{PSU}$ and $38^{\circ} \mathrm{C}$, respectively, compared to $50 \mathrm{PSU}$ and $35^{\circ} \mathrm{C}$ at the surface (C. Kelble, NOAA, pers. comm.).

In response to this major seagrass die-off, FWC biologists surveyed Florida Bay 3 times between July 2015 and January 2016. Our intention was to provide spatially explicit information regarding the recurrence of a major ecological event in Florida Bay so that investigators interested in issues such as climate change, Everglades restoration, sulfide toxicity, ecosystem resilience and recovery would have the opportunity to plan work in the area before the occurrence of anticipated cascading disturbances (e.g. algal blooms, sediment re-suspension and sponge die-offs).

\section{METHODS AND RESULTS}

In August 2015, we conducted an exploratory survey throughout north-central Florida Bay to estimate the spatial extent, severity and physical appearance of the current mortality as compared to the 1987 event. Remaining pockets of 'yellow fog' were observed in small depressions within large swaths of dead Thalassia testudinum in Garfield Bight, Rankin Lake and Johnson Key Basins (Fig. 1a). Affected beds exhibited a range of conditions from 'standing dead', where leaf material appeared green despite having dead meristematic tissue, to stands of heavily bleached aboveground biomass, to large areas of 'stubble' comprised of only basal leaf sheaths (Fig. S2 in the Supplement at www.int-res.com/articles/suppl/ m560p243_supp.pdf). These conditions coincided with large (100s of $\mathrm{m}^{2}$ ) floating mats of freshly sloughed aboveground biomass (Fig. S3 in the Supplement). This floating detritus was unusual in having a high proportion of leaves still connected to dead shoot meristems. This is normally not observed during seasonal leaf senescence or defoliation, which follows brief periods of sub-lethal stress. In late September-early October 2015, FHAP locations from the previous May were resampled in Whipray, Twin Key and Rabbit Key Basins (29-31 sites basin ${ }^{-1}$, Fig. 1a) and from the previous 2 springs (60 sites basin ${ }^{-1}$ ) in Rankin Lake and Johnson Key Basin (the most impacted areas during the 1987 event, Fig. 1a). These stations were originally selected by partitioning each basin into 29-31 tessellated hexagonal grid cells and randomly selecting 1 location per cell. At each station, seagrass and macroalgal coverage were visually quantified within each of 8 haphazardly distributed $0.25 \mathrm{~m}^{2}$ quadrats using a modified Braun-Blanquet frequency abundance scale (Mueller-Dumbois \& Ellenburg 1974, Durako et al. 2002). We also determined the presence or absence of $T$. testudinum mortality within the vicinity of the boat. During the late September-early October 2015 sampling, considerably more floating detritus was observed than during the August survey (Fig. S4 in the Supplement); however, it appeared more degraded and seemed to be undergoing diurnal vertical movements to and from the sediment surface, as detritus buoyed by attached bubbles was noted at multiple levels in the water column (Fig. S5 in the Supplement). In January 2016, systematic visual surveys of die-off were conducted in what were operationally called Pelican, Palm and Man-of-War Basins (Fig. 1a). These additional locations are not included in FHAP surveys, but are areas where die-off was suspected. The presence of well-defined areas of recently dead seagrass shoots was assessed from the boat (height of $2 \mathrm{~m}$ ) every $100 \mathrm{~m}$ where the bottom remained visible and every $500 \mathrm{~m}$ by diver when it was not. By January, areas of dead seagrass shoots were observed at spatial scales from patches $<1 \mathrm{~m}^{2}$ to the complete loss of entire basins $\left(10 \mathrm{~s}\right.$ of $\left.\mathrm{km}^{2}\right)$. At some locations, remnant surviving patches of various sizes were interspersed within once continuous meadows. As was noted during the 1987 event, many of the die-off boundaries were sharply delineated. Although this gave the impression of an ongoing event, early winter rains had reduced salinities and no fresh or floating detritus was observed. Unattached aboveground biomass not flushed from the system by wind and tidal currents was now distributed on the benthos in 
dense mats of $10-20 \mathrm{~cm}$ (in some places $>50 \mathrm{~cm}$ ) thickness (Fig. S6 in the Supplement). In northern Rankin Lake Basin and several other locations, expansive beds (100s to $1000 \mathrm{~s}$ of $\mathrm{m}^{2}$ ) of the green macroalgae Batophora sp. had recently recruited to the surface of the detrital layer. This species was also reported as an early colonizer following the previous die-off event (Thayer et al. 1994).

\section{DISCUSSION}

Using the spatial data gathered during site visits, polygons representing areas of severe seagrass mortality were developed using ArcGIS (Fig. 1b). Estimated at 8777 ha and concentrated in north-central Florida Bay, the current die-off is nearly equivalent to the 1987 event in terms of its size, location, seasonality, speed, species specificity and gross appearance. A lack of continuous environmental data prevents direct comparison of bottom-water conditions between the 2 die-offs; however, ecophysiological stress resulting from high pore- and bottom-water sulfide levels may be common to both events (P. Carlson unpubl. data). Less clear are the climatic conditions needed to precipitate hypoxic stress within the densest meadows, as prolonged drought preceded the most recent die-off, yet mainly followed the 1987 occurrence. It may well be that a combination of several meteorological events during the warmer seasons can lead to excessive evaporation (lack of rain, reduced freshwater inflow and low cloud cover) or stratification (low wind velocities) in this portion of the bay, complicating long-term predictions of die-off risk and upstream water management. Recent work by Lee et al. (2016) suggests that minor modifications of freshwater water delivery to McCormick Creek during the dry season may alleviate hypersalinity in the northcentral region of Florida Bay; however, temperature stress and in situ (i.e. bank top) brine production during drought years or during delayed wet seasons may still negatively impact seagrass communities. The unique combination of very dense $T$. testudinum and sustained, $15 \mathrm{yr}$ high salinities coincident with elevated and increasing summertime water temperatures may have resulted in a tipping point that exceeded the physiological tolerances of this species (Figs. 2 \& 3).

Acknowledgements. The authors thank the South Florida Water Management District for funding under the Restoration, Coordination, and Verification Program, and Everglades National Park for substantial logistical support. Our work would not have been possible without the assistance of many UNCW graduate students and FWC seagrass team members over the past $22 \mathrm{yr}$, particularly Donna O'Dell, Katie Toth, Mike Wheeler, Robin Jung, Nathan Gavin, Brooke Landry and Jennifer Kunzelman Hart.

\section{LITERATURE CITED}

Boesch DF, Armstrong NE, D'Elia CF, Maynard NG, Paerl HW, Williams SL (1993) Deterioration of the Florida Bay ecosystem - an evaluation of the scientific evidence. Report to the Interagency Working Group on Florida Bay. National Fish and Wildlife Foundation, Washington, DC

Borum J, Pedersen O, Greve TM, Frankovich TA, Zieman JC, Fourqurean JW, Madden CJ (2005) The potential role of plant oxygen and sulphide dynamics in die-off events of the tropical seagrass, Thalassia testudinum. J Ecol 93:148-158

Butler IV MJ, Hunt JH, Herrnkind WF, Childress MJ and others (1995) Cascading disturbances in Florida Bay, USA: cyanobacteria blooms, sponge mortality, and implications for juvenile spiny lobsters Panulirus argus. Mar Ecol Prog Ser 129:119-125

Carlson PR, Yarbro LA, Barber TR (1994) Relationship of sediment sulfide to mortality of Thalassia testudinum in Florida Bay. Bull Mar Sci 54:733-746

Durako MJ, Kuss KM (1994) Effects of Labyrinthula infection on the photosynthetic capacity of Thalassia testudinum. Bull Mar Sci 54:727-732

Durako MJ, Hall MO, Merello M (2002) Patterns of change in the seagrass-dominated Florida Bay hydroscape. In: Porter JW, Porter KG (eds) Linkages between ecosystems in the south Florida hydroscape: the river of grass continues. CRC Press, Boca Raton, FL, p 515-529

Fourqurean JW, Robblee MB (1999) Florida Bay: a history of recent ecological changes. Estuaries 22:345-357

Fourqurean JW, Zieman JC, Powell GVN (1992) Phosphorus limitation of primary production in Florida Bay-evidence from C:N:P ratios of the dominant seagrass Thalassia testudinum. Limnol Oceanogr 37:162-171

Hall MO, Madley K, Durako MJ, Zieman JC, Robblee MB (2007) Florida Bay. In: Handley L, Altsman D, DeMay R (eds) Seagrass status and trends in the Northern Gulf of Mexico: 1940-2002, U.S Geological Survey Scientific Investigations Report 2006-5287 and U.S. Environmental Protection Agency 855-R-04-003

Kendrick GA, Fourqurean JW, Fraser MW, Heithaus MR, Jackson G, Friedman K, Hallac D (2012) Science behind management of Shark Bay and Florida Bay, two P-limited subtropical systems with different climatology and human pressures Introduction. Mar Freshw Res 63: 941-951

- Koch MS, Schopmeyer SA, Nielsen OI, Kyhn-Hansen C, Madden CJ (2007) Conceptual model of seagrass die-off in Florida Bay: links to biogeochemical processes. J Exp Mar Biol Ecol 350:73-88

Lapointe BE, Barile PJ (2004) Comment on J. C. Zieman, J. W. Fourqurean, and T. A. Frankovich. 1999. Seagrass dieoff in Florida Bay: long-term trends in abundance and growth of turtle grass, Thalassia testudinum. Estuaries 22:460-470. Estuaries 27:157-164

Lee TN, Melo N, Johns E, Kelble C, Smith RH, Ortner P (2008) On water renewal and salinity variability in the 
northeast subregion of Florida Bay. Bull Mar Sci 82: 83-105

Lee NL, Melo N, Smith N, Johns EM, Kelble CR, Smith RH, Ortner PB (2016) Circulation and water renewal of Florida Bay, USA. Bull Mar Sci 92:153-180

Marshall FE, Wingard GL, Pitts PA (2014) Estimates of natural salinity and hydrology in a subtropical estuarine ecosystem: implications for greater everglades restoration. Estuaries Coasts 37:1449-1466

Mueller-Dumbois D, Ellenburg H (1974) Aims and methods of vegetation ecology. John Wiley \& Sons, New York, NY

Nuttle WK, Fourqurean JW, Cosby BJ, Zieman JC, Robblee MB (2000) Influence of net freshwater supply on salinity in Florida Bay. Water Resour Res 36:1805-1822

Peterson BJ, Chester CM, Jochem FJ, Fourqurean JW (2006) Potential role of sponge communities in controlling phytoplankton blooms in Florida Bay. Mar Ecol Prog Ser 328:93-103

Robblee MB, Barber TR, Carlson Jr PR, Durako MJ and others (1991) Mass mortality of the tropical seagrass Thalassia testudinum in Florida Bay (USA). Mar Ecol Prog Ser 71:297-299

Rudnick DT, Chen Z, Childers DL, Boyer JN, Fontaine TD (1999) Phosphorus and nitrogen inputs to Florida Bay: the importance of the everglades watershed. Estuaries 22:398-416

Schomer NS, Drew RD (1982) An ecological characterization

Editorial responsibility: Charles Peterson,

Morehead City, North Carolina, USA of the lower Everglades, Florida Bay and the Florida Keys. US Fish and Wildlife Service, Office of Biological Services, Technical Report/FWS/OBS 82/58.1, Washington, DC

Thayer GW, Murphey PL, Lacroix MW (1994) Responses of plant-communities in western Florida Bay to the die-off of seagrasses. Bull Mar Sci 54:718-726

Wang JD, Vandekreeke J, Krishnan N, Smith D (1994) Wind and tide response in Florida Bay. Bull Mar Sci 54:579-601

Zieman JC (1997) Florida Bay seagrass die-off. In: Gallagher D, Causey JD, Gato J, Viele J (eds) The Florida Keys environmental story, a panorama of the environment, Culture and History of Monroe County. Seacamp Association, Marathon, FL, p 264-267

Zieman JC, Fourqurean JW, Iverson RL (1989) Distribution, abundance and productivity of seagrasses and macroalgae in Florida Bay. Bull Mar Sci 44:292-311

Zieman JC, Fourqurean JW, Frankovich TA (1999) Seagrass die-off in Florida Bay: long-term trends in abundance and growth of turtle grass, Thalassia testudinum. Estuaries 22:460-470

Zieman JC, Fourqurean JW, Frankovich TA (2004) Reply to B. E. Lapointe and P. J. Barile (2004). Comment on J. C. Zieman, J. W. Fourqurean, and T. A Frankovich. 1999. Seagrass die-off in Florida Bay: long-term trends in abundance and growth of turtle grass, Thalassia testudinum. Estuaries 22: 460-470. Estuaries 27:165-172

Submitted: May 30, 2016; Accepted: October 5, 2016

Proofs received from author(s): November 21, 2016 